\title{
ОСОБЛИВОСТІ РИНКУ ОСВІТНІХ ПОСЛУГ І ПРОБЛЕМА ВЗАЕМОДІї ВНЗ З РОБОТОДАВЦЯМИ
}

\author{
Лавриненко Л. М. \\ к.е.н., Інститут економіки та прогнозування НАН Украӥни, Київ, Україна
}

DOI: https://doi.org/10.31435/rsglobal_ijite/31052020/7068

\section{ARTICLE INFO}

Received 29 March 2020

Accepted 19 May 2020

Published 31 May 2020

\section{KEYWORDS}

education,

educational services market, interaction,

labor market,

quality of educational

services,

employers,

skilled personnel.

\begin{abstract}
The purpose of the article is to analyze the current processes that are taking place in the field of training for the national economy of Ukraine, and to develop ways to improve the effectiveness of interaction and interconnection of labor markets and educational services. The problem of social partnerships between higher education institutions and the real economy is investigated. This paper analyzes the foreign experience of networking universities with employers, and highlights the successes and challenges of this process. The content of the mechanism of interaction between customers and consumers in the educational services market is considered. It also offers suggestions on how to make the education market more up-to-date and adapted to the development of everything new in the Ukrainian labor market. The necessity of regulating the interaction of educational services and labor markets is substantiated. It is proved that only the interaction of professional educational institutions, employers and the state can ensure the effective functioning of the market of educational services, which provides the balance of demand and supply of qualified personnel necessary for the successful economic development of the country.
\end{abstract}

Citation: Лавриненко Л. М. (2020) Osoblyvosti Rynku Osvitnikh Posluh i Problema Vzaiemodii VNZ $\mathrm{z}$ Robotodavtsiamy. International Journal of Innovative Technologies in Economy. 2(29). doi: 10.31435/rsglobal_ijite/31052020/7068

Copyright: (ㄷ 2020 Лавриненко Л. М. This is an open-access article distributed under the terms of the Creative Commons Attribution License (CC BY). The use, distribution or reproduction in other forums is permitted, provided the original author(s) or licensor are credited and that the original publication in this journal is cited, in accordance with accepted academic practice. No use, distribution or reproduction is permitted which does not comply with these terms.

Вступ. Сьогодні у всьому світі зростає інтерес до розуміння цінності освіти, науки як чинника добробуту суспільства, його конкурентоспроможності на світовому ринку. Місце $\mathrm{i}$ роль будь-якої держави в світовому співтоваристві в умовах нової економіки, перш за все, пов'язані з його здатністю виробляти, споживати і застосовувати нові знання і технології.

Освіта виступає основним соціальним інститутом, яка задовольняє потреби суспільства у формуванні кваліфікованої робочої сили, у збереженні та розвитку системи наукових знань, у забезпеченні соціалізації підростаючого покоління, формуванні загальної культури та соціальних норм. Із зростанням вагомості людського капіталу, як основного чинника економічного розвитку, вища освіта стає найважливішим засобом формування нової генерації висококваліфікованих кадрів та розвитку інтелектуального потенціалу [1].

Освіта та професійна підготовка $є$ фундаментом людського розвитку і прогресу суспільства. Вони також виступають гарантом індивідуального розвитку, виховують інтелектуальний, духовний та виробничий потенціал суспільства. Нові знання, які генеруються наукою, підготовка високоякісного людського капіталу на базі якісної освіти побудованого на знаннях. Розвиток держави, структурні перетворення на мікро- та макроекономічному рівнях мають гармонійно поєднуватись із реформою освіти, професійною підготовкою для того, щоб задовольнити потреби та прагнення людей.

Тісна взаємодія ринку праці та ринку освітніх послуг в умовах трансформації економіки залишається важливим чинником змін і появи нових тенденцій в освітньому просторі, формування людського капіталу як основи ефективного економічного і соціального розвитку 
країни. Їх вплив на професійне навчання та професійну орієнтацію населення, особливо молоді, $\epsilon$ важливим і актуальним питанням національної безпеки держави. Без його вирішення неможливе формування якісно нової робочої сили, забезпечення кваліфікованими кадрами економіки країни, зменшення обсягів безробіття.

Результати дослідження. Сьогодні світова спільнота знаходиться на етапі кардинальної трансформації економічних систем та суспільних відносин. Стрімкий розвиток та поширення цифрових технологій не лише відкриває нові можливості для розвитку держави та всіх сфер іiі економіки, а й створюють нові виклики. Основним викликом для сучасного суспільства $є$ зростання потреби у високоосвічених фахівцях, які здатні не лише використовувати вже набуті компетентності, а й постійно оновлювати їх, враховуючи тенденції розвитку світової економіки. Економічний розвиток, соціальний добробут суспільства $\epsilon$ неможливий без наявності висококваліфікованих кадрів.

Розвиток суспільства, заснованого на знаннях, можливий тільки за умови інноваційного шляху побудови економіки та розвитку високотехнологічного виробництва. Для здійснення ефективного керівництва інноваційними процесами, розробки й впровадження інноваційних проектів необхідні висококваліфіковані фахівці. Формування конкурентоспроможної економіки, загострення конкуренції на внутрішньому і зовнішніх ринках вимагає від кадрів вищого рівня кваліфікації, здатності до ризику, генерування нових ідей та творчості, готовності до змін і відповідальності. У цих умовах особливо зростає роль навчальних закладів та якість надання освітніх послуг. Однією з актуальних завдань розвитку сучасної економіки є організація тісної взаємодії освітніх установ із підприємствами-роботодавцями. Вузи, будучи центрами мережевої взаємодії, являють собою відкриті системи, що приділяють увагу розвитку внутрішньої інтеграції, спрямованої на підвищення якості освіти, організацію системи безперервної освіти, а також підготовці кваліфікованих конкурентоспроможних випускників. Щодо динамічно розвитку української економіки для успішної діяльності щодо виходу на світові ринки необхідна інноваційна технологічна революція, а вищі навчальні заклади сьогодні нажаль не в змозі готувати кадри, здатні забезпечити цей прорив. Тому підготовка мобільних, кваліфікованих професіоналів, безперечно в умовах, які визначають необхідність формування національних пріоритетів у сфері інноваційної освіти 3 урахуванням світових тенденцій, які визначають постійну потребу у підвищенні професійної кваліфікації майбутніх фахівців. Освіту слід розглядати як одну із найважливіших підсистем організованої соціалізації сучасного суспільства, яка забезпечує процес отримання людиною систематизованих знань, вмінь та навичок 3 метою їх подальшого ефективного використання у своїй професійній діяльності в інтересах особистості, суспільства та держави.

Слід сказати, що забезпечення економічного зростання багато в чому визначається кадровим потенціалом, рівнем його підготовки, кваліфікації та освіти [2]. Сьогодні перед освітою стоїть складне завдання - забезпечити постійну адаптацію людини до змін в навколишньому світі, створити систему безперервної освіти. Тільки таким чином можна забезпечити високу конкурентоспроможність національної вищої школи в умовах глобалізації, щоб вона сприяла просуванню своєї країни на міжнародному ринку праці, стала провідним елементом сучасної геополітики і засобом успішної реалізації економічної стратегії держави. Рівень якості підготовки фахівців - основний показник, який визначає статус університету, тому позиціонування вищого навчального закладу на ринку освітніх послуг у більшій мірі залежить від ефективності його соціального партнерства із підприємствами реального сектора економіки - споживачами майбутніх випускників. Організація мережевої взаємодії освітніх установ із підприємствами реального сектора економіки дозволяє підсумувати інформаційні, технологічні інноваційні наукові ресурси для досягнення принципово нової якості професійної підготовки кваліфікованих працівників із урахуванням задоволення потреб ринку праці.

На нашу думку підприємства можуть бути не тільки замовниками і споживачами випускників освітніх організацій, а й повинні бути зацікавлені у спільних науково-дослідних роботах. Підприємства повинні стати джерелом докторантів, аспірантів й здобувачів, які будуть виконувати свої дослідження на актуальні для підприємства теми, та приносити реальну практичну користь підприємству. Таким чином, повинна економіка бути зацікавленою в ефективній мережевій взаємодії з освітніми організаціями вищої освіти.

Проблема взаємозв'язку освітніх організацій та підприємств-роботодавців, як один із способів вирішення питань сучасної економіки, випуску кваліфікованих кадрів та залучення до університетів додаткових фінансових коштів, актуальна для всього світу. Проаналізувавши 
закордонні джерела на підставі наукових робіт дослідників із Норвегії, Китаю, Німеччини, Франції, Бразилії, Японії, Мексики чітко можна визначити, що пошук вирішення зазначеної проблеми вже досить тривалий час займає політичних діячів і вчених багатьох розвинених країн та країн, що розвиваються.

У зарубіжній практиці можна виділити три основні моделі партнерства університетів із реальним сектором економіки.

1. Значення держави незначне (Великобританія, США). Особливістю взаємодії ринку освіти та підприємств в США $є$, з одного боку, накопичені бізнесом практичні знання важливі для становлення освітнього простору, а 3 іншого - успішна кар'єра недосяжна без наявності університетського ступеня. Установи вищої професійної освіти здебільшого незалежні від держави, як з точки зору джерел фінансування, так і у плані розробки освітніх програм.

В Англії державна політика в галузі вищої професійної освіти в більшості випадків визначається на регіональному рівні, та центральну роль відіграють роботодавці майбутніх випускників. Успішно функціонує мережа галузевих рад із розвитку професійних навичок. Участь роботодавців направлено на формалізацію вимог робочих місць відповідно до кваліфікації випускників та розвиток профільних освітніх структур.

2. Держава планує, реалізує й управляє професійною освітою (Франція, Швеція). Для даної моделі партнерської взаємодії системи освітніх послуг та ринку праці характерний, перш за все, високий рівень державного регулювання сфери професійної освіти.

У Франції контроль якості професійної освіти здійснюється насамперед державними органами, проте соціальні партнери беруть участь у процесі прийняття рішень через тристоронні консультативні органи. Відроджена програма «учнівства» (частина навчання проходить у рамках формальної освіти, практичне навчання та відбір проводиться підприємством) у Франції.

Швецію характеризує політика активної підтримки трудових ресурсів (забезпечення географічної мобільності випускників; створення банку даних, що надають повну інформацію про вакантні місця за професіями й галузям; фінансування роботи у приватних фірмах молоді) i велика увага приділяється профорієнтації, яка попереду професійного навчання.

3. На державу покладено розподіл загальних рамок діяльності приватних підприємств та організацій щодо здійснення професійної освіти та навчання (Німеччина, Нідерланди, Данія, Шотландія).

Для Німеччини характерні концентрація та інтеграція освітніх ресурсів. Для вирішення проблеми успішного працевлаштування випускників розроблені ряд програм (система, що сягала історичної традиції навчання підмайстрів у різних малих підприємствах; модель «трудового року»; центри професійної освіти).

У Нідерландах створено недержавні Національні ради за професійними профілями. Їх метою є посилення ступеню відповідності вимог роботодавців щодо якості професійного навчання. Разом із соціальними партнерами Національні ради визначають зміст програм навчання та кваліфікаційні вимоги до випускників.

У Данії система вищої професійної освіти орієнтована на вузьку спеціалізацію.

У Шотландії розробкою та оцінкою професійних кваліфікацій випускників займається неурядова організація - Шотландське кваліфікаційне управління, яке зорієнтовано на розвиток взаємодії між роботодавцями та системою освіти.

На відміну від зарубіжних країн, які досягли певних успіхів щодо взаємодії вищої професійної освіти й роботодавців, в Україні існує суперечність між назрілою необхідністю соціального партнерств вузів із реальним сектором економіки та неготовністю більшості українських роботодавців здійснювати ефективну взаємодію із університетами. Дане протиріччя обумовлено нечіткістю вимог до компетенцій співробітників та відсутністю розроблених форм і методів ведення продуктивного діалогу між сторонами.

Сучасний ринок праці визначається двома суперечливими тенденціями, узгодження яких дасть змогу збалансувати і кількісні, i, найголовніше, якісні показники попиту та пропозиції робочої сили на ринку праці. Рисою соціально-економічної стратегії розвитку стає усвідомлення того, що інвестиції в людський капітал є найбільш ефективними. Усі люди в певній мірі відчувають потребу у знаннях, яка задовольняється у процесі отримання освіти. 3 точки зору суспільного блага освітні послуги можуть бути визначені як засіб задоволення потреби в освіті, визначення та задоволення якої відбувається саме на ринку освітніх послуг. Перш за все, в теорії управління якістю послуга повинна бути спрямована на конкретного споживача. ВУЗу необхідно 
визначити неочікувані та очікувані потреби конкретних споживачів для того, щоб у достатній мірі задовольнити освітні потреби. А це означає, що освітня послуга - це діяльність, метою якої $\epsilon$ задоволення очікуваних та неочікуваних освітніх потреб конкретних споживачів.

3 точки зору роботодавця, випускники вузів повинні володіти як мінімум наступними характеристиками:

- володіти достатніми практичними та теоретичними знаннями, для того, щоб була забезпечена висока продуктивність праці, знижені витрати підприємства на донавчання молодих фахівців, перепідготовку кадрів;

- мати необхідні для сучасного виробництва особистісні якості: ініціативність, цілеспрямованість, високу мотивацію на досягнення успіху, здатність працювати в команді, креативність, здатність та прагнення до самонавчання і саморозвитку, стресостійкість, відповідальність і т. п.;

- володіти високою працездатністю, що означає наявність фізичної витривалості та міцного здоров'я.

Щоб реалізуватися в житті та зайняти гідне становище у суспільстві, особистості потрібно отримати в процесі освіти:

- теоретичні знання, практичні вміння, навички, які знадобляться для того, щоб здійснювати свою майбутню діяльність, приносити користь суспільству та отримувати дохід;

- рівень інтелекту, який передбачає вміння вирішувати завдання різної складності та характеру, а також абстрактне мислення;

- розвинені професійні та особистісні якості;

- ряд особистісно-психологічних характеристик, до яких відносяться організаторські здібності, відповідальність за вчинені дії та ін.;

- здоров'я особистості та їі фізичні навички, які сприяють забезпеченню високої працездатності;

- високий рівень культури та виховання.

Також можна виділити ряд вимог, які відображають потреби суспільства у вищій освіті:

- здійснення підготовки висококваліфікованих кадрів, які повинні справитися із завданнями (в тому числі й творчими), проводити як прикладні, так і фундаментальні дослідження, що забезпечують прогрес у всіх областях знань та галузях народного господарства;

- підготовка кадрів високої кваліфікації, які вміють максимально ефективно вирішувати практичні завдання, які стосуються різних галузей діяльності;

- виховання високоосвічених та культурно розвинених людей для збереження та збагачення національної культури;

- підготовка здорових та фізично розвинених особистостей за допомогою фізичного виховання студентів.

Незважаючи на єдність інтересів особистості учня, роботодавця та суспільства в теорії, на практиці існує певна неузгодженість, розрив між інтересами освітніх інститутів, що надають освітні послуги та роботодавцями, які $є$ в кінцевому підсумку споживачами «продукту» освітнього процесу. Сьогодні освітні установи недостатньо орієнтовані на підготовку випускників, які володіють тими професійними та особистісними якостями, які дійсно затребувані роботодавцями. Одна із головних претензій останніх до вузів - відірваність теоретичних знань молодих фахівців від практики. Даний недолік проявляється у невмінні поводитися із сучасним обладнанням, в психологічну неготовність працювати на сучасному виробництві: керувати робітниками, вміння вести себе у бізнес-середовищі та ін. Роботодавці зацікавлені сьогодні не тільки в робочих або фахівцях, а перш за все у висококваліфікованих фахівцях, які володіють новітніми технологіями, знають сучасну техніку та обладнання. І завдання навчальних закладів - підготувати таких фахівців.

Ще однією актуальною проблемою партнерських взаємин університетів із реальним сектором економіки є відсутність ефективної системи аналізу ринку праці з боку освітніх установ, що $\epsilon$ серйозною перешкодою на шляху формування затребуваних кваліфікованих фахівців. Така невідповідність породжує проблеми працевлаштування випускників професійних навчальних закладів, проблему дефіциту необхідних кадрів для підприємств, що в результаті створює дисбаланс попиту та пропозиції праці кваліфікованих працівників на ринку. Ситуація ускладнюється слабкою орієнтацією системи освіти у визначенні структури підготовки фахівців на дійсні потреби роботодавців; платність освітніх послуг орієнтує вищі навчальні заклади на збільшення набору на ті спеціальності, які затребувані абітурієнтами, 
часто слабо або неправильно поінформованими про реальну ситуацію на ринку праці. Але й це, далеко не єдина проблема, яку треба буде розв'язати на шляху ефективної взаємодії зацікавлених сторін при розробці освітніх програм та формуванні кваліфікованих кадрів.

Для створення ринку науково-освітніх послуг на європейських засадах необхідно забезпечити:

- підвищення якості освіти;

- введення культури самоосвіти та освіти впродовж життя;

- стимулювання розвитку творчих навичок, прояву індивідуальних здібностей, талантів людей;

- підвищення рівня розуміння студентами того, що знання, які вони отримають, допоможуть у майбутній кар'єрі.

Система освіти практично відособлена від реального сектора економіки, хоча у величезній мірі залежить від нього. Вже згадана проблема $є$ наслідком того, що українські університети в певний період часу були змушені планувати економічний розвиток, орієнтуючись виключно на внутрішнє середовище, тому що зовнішні обмеження практично їх не стосувалися. Підсумком цього стало те, що українські університети часто самі прагнуть ізолювати себе від того, що відбуваються навколо змін, що негативно позначається на їх адаптаційні можливості, i, тим більше, їх передбачення. Освітня діяльність вузів часто організована таким чином, що вони самі формулюють вимоги до підготовки майбутніх фахівців.

При цьому саме освіта повинна відігравати ключову роль у забезпеченні економіки компетентними, високопрофесійними працівниками, тим самим сприяючи стабільному довгостроковому економічному та соціальному розвитку країни. Для того, що б система освіти у повній мірі могла виконувати зазначену роль в сучасних ринкових умовах, необхідна ефективна система взаємодії професійних навчальних закладів та роботодавців за активної участі держави. Основою такого співробітництва може виступати система соціального партнерства, яка буде сприяти не тільки підвищенню ефективності навчання, а й розвитку системи навчання із урахуванням потреби особистості, підприємств та суспільства; сприяти забезпеченню рівного доступу до навчання, досягнення безперервного соціально-економічного розвитку.

Взаємодія зазначених суб'єктів має будуватися на основі принципів рівноправності сторін, поваги та врахування інтересів усіх сторін, систематичності та послідовності взаємодії, добровільності прийняття зобов'язань, зацікавленості сторін у досягненні поставлених цілей, реальності прийнятих на себе зобов'язань та обов'язковість їх виконання, відповідальності сторін. Сьогодні існують різноманітні форми взаємодії вузів та роботодавців, що сприяють приведенню у відповідність структури та рівня підготовки випускників навчальних закладів вимогам роботодавців. До цих форм можна віднести участь роботодавців у коригуванні професійних освітніх програм, участь у навчальному процесі ВНЗ (читання лекцій, керівництво виробничою практикою студентів), цільові замовлення підприємств вузу на підготовку кадрів, проведення спільних науково-практичних конференцій, семінарів, круглих столів та багато іншого.

Зокрема, при орієнтації спільної освітньої діяльності на реальний сектор економіки необхідно дотримуватися таких умов:

1. Систематична робота з пошуку взаємодії із соціальними партнерами 3 того чи іншого боку, як в університетах, так і всередині підприємств. Спільні наукові дослідження, патенти, цільова підготовка фахівців можуть поліпшити взаємодію цих секторів.

2. Вузу повинна бути забезпечена гідна інфраструктура. Він не повинен перетворюватися в мале підприємство, яке працює лише на потреби окремих секторів економіки. Проте, сукупність малих підприємств, бізнес в цілому, система освітніх майданчиків користування інформацією, науково-дослідних лабораторій, патентні центри, робить їх ефективними з точки зору й економіки, та навчальних організації; розвивати наукові колективи висококваліфікованих фахівців із залученням працівників із реального сектора економіки.

3. Наявність інформаційних, інноваційних, технологічних ресурсів, що роблять ставку на соціальне партнерство університету й підприємства.

Будь-яке управлінське та матеріальне стимулювання спільної діяльності різних університетів із реальним сектором економіки є позитивним для обох сторін, тому що об'єднання інтелектуальних ресурсів двох організацій підвищує ефективність їх діяльності та гарантує успіх проектних заявок, сприяє організації мережевої взаємодії між цими великими секторами вітчизняної економіки. 
Неодмінною умовою даної взаємодії $\epsilon$ активна регулююча та координуюча роль держави в особі органів державної влади. Формами участі держави в даному процесі можуть бути розробка та реалізація регіональних програм підтримки молодих фахівців із дефіцитними спеціальностями, моніторинг ринку праці, організація ярмарків вакансій для випускників, профорієнтаційна робота із абітурієнтами та учнями шкіл, надання премій та стипендій студентам, грантова підтримка, цільовий прийом у вузи в інтересах розвитку економіки регіону, організація освітньо-виробничих комплексів та багато іншого.

Подолання економічних, соціальних та політичних кризових явищ українського суспільства можливе лише за умов сприйняття, що вища освіта повинна відповідати сучасним потребам суспільства та ринку праці, забезпечувати формування у кожної особистості здатності швидко адаптуватися до сучасних соціо-економічних реалій, які стають найважливішою умовою успішного і стійкого розвитку соціуму. В якості одного з напрямків взаємодії вищої школи та реального сектора економіки можна представити участь організацій вищої освіти в організації перспективної перепідготовки та підвищення кваліфікації кваліфікованих фахівців для конкретних підприємств. Також представляється необхідно приділяти адекватну увагу об'єднанню зусиль підприємств і вузів в адаптації молодих фахівців.

Сьогодні перед наукою та освітою ставляться принципово нові завдання. Головна 3 них полягає у тому, щоб наукові та освітні організації перетворити в активних учасників інноваційного процесу, дієвих стимуляторів розвитку продуктивних сил. Реалізація такого підходу неможлива без вдосконалення діючих форм інтеграції та впровадження нових перспективних моделей співпраці науки та освіти з виробництвом. Саме ефективна інтеграція сфер економіки (науки, освіти і виробництва), як переконливо доводить світовий досвід, забезпечує провідні позиції країн у міжнародній конкуренції, підвищує науково-технологічний потенціал і ефективність економічних процесів.

Висновки. Таким чином, подолання освітньо-кваліфікаційного дисбалансу є не стільки питанням підвищення ефективності функціонування ринку праці як такого, скільки наочним відображенням широкого кола проблем, які накопичилися у сфері управління розвитком людського капіталу. Їх вирішення можливе лише за умов системного визначення стратегічних цілей та завдань розвитку держави із урахуванням принципів гідної праці, пріоритетів промислово-економічної, соціальної, демографічної, освітньої та наукової політики. Отже, тільки взаємодія професійних навчальних закладів, роботодавців та держави може забезпечити ефективне функціонування ринку освітніх послуг, що забезпечує баланс попиту та пропозиції кваліфікованих кадрів, необхідний для успішного економічного розвитку країни.

\section{ЛІТЕРАТУРА}

1. Лавриненко, Л. (2016). Взаємодія та взаємозв'язок ринку праці та ринку освітніх послуг. // Глобальні та національні проблеми економіки. 2016 (9). 592-596. - URL: http://global-national.in.ua/avtoram/

2. Міщук, Н. (2019). Освіта як чинник конкурентоспроможності молоді на ринку праці. Інноваційна економіка. 1-2 [78]. 80-86.

3. Лавриненко, Л. (2016). Проблемы взаимодействия современной системы образования и рынка труда. // Актуальные проблемы социально-трудовых отношений. Матеріали конференцій. Махачкала. 214-216. URL: https://aprobacia.ru/assets/images/knigi/titul-rag.pdf/

4. Лавриненко, Л. (2015). Ринок праці в Україні та соціальна функція держави. // Інноваційна економіка. 2’2015 [57]. 154-159.

5. Лавриненко, Л. (2019). Світовий досвід професійного навчання та розвитку персоналу. // Управління соціально-економічними трансформаціями господарських процесів: реалії і виклики. Матеріали конферениій. Мукачево. МДУ. 326-329.

6. Лавриненко, Л. (2018). Мотиваційна складова професійної компетентності. // Конкурентоспроможність вищої освіти України в умовах інформаційного суспільства. Матеріали конференцій. Чернігів. нац. технол. ун-т. 510-512. URL: https://www.stu.cn.ua/media/files/conference/konkup18-z.pdf/

7. Лавриненко, Л. (2016). Творческий труд и креативность в инновационной среде. // Науковий вісник Мукачівського державного університету. Серія «Економіка». 2(6). 85-91.

8. Лавриненко, Л. (2020). Проблеми формування інфраструктури ринку праці в Україні й вдосконалення розвитку його інститутів. // Eurasian scientific congress. Abstracts of the 2ndInternational scientific and practical conference. Barca Academy Publishing. Barcelona, Spain. 2020. 488-492. URL: http://sci-conf.com.ua

9. Лавриненко, Л. (2020). Освіта в реальності сьогодення - дистанційне навчання. Матеріали конферениій МЦНД, 25-28. URL: https://doi.org/10.36074/10.04.2020.v1.01/ 